Arabiyat : Jurnal Pendidikan Bahasa Arab dan Kebahasaaraban

\title{
USING INSTAGRAM ON ARABIC LEARNING IN THE POST-PANDEMIC ERA: STUDENTS' VOICES
}

\author{
Ahmad Habibi Syahid ${ }^{1}$, Mehrunnisa ${ }^{2}$ \\ ${ }^{1}$ Universitas Islam Negeri Sultan Maulana Hasanuddin Banten, Indonesia \\ Jl. Jendral Sudirman No. 30, Panancangan Cipocok Jaya, Kota Serang, Banten, 42118, Indonesia \\ ${ }^{2}$ Middle East Technical University, Ankara, Turkey \\ Üniversiteler, Dumlupinar Blv. 1/6 D:133, 06800, Ankara, Turkey \\ Corresponding E-mail:abmad.habibi@uinbanten.ac.id
}

\begin{abstract}
The aim of this study was to investigate whether the use of Instagram on Arabic learning in the post-pandemic era can be one of the solutions for communicative online teaching and learning. Previous studies showed that the student found difficulties because of the lack of adequate facilities and infrastructures to use online platforms. However, the other student could use and operate it easily. This article discusses students' perspectives on learning using Instagram, especially in improving Arabic language skills. The most supportive facility and infrastructure in conducting online learning is the presence of technology. In online learning, the learning management system that has already been widely used in online distance learning. However, today, social media such as Instagram can be used as a learning tool. The result of this study showed that Instagram was one of the solutions for communicative online teaching and learning in the pandemic and post-pandemic era according to the student perspective. Using descriptive analysis in describing the findings, the qualitative was chosen as the method in this study.
\end{abstract}

Keywords: $\quad$ instagram, Arabic learning, pandemic era, post-pandemic era

\section{Introduction}

One year and eight months since the Sars-Cov2 virus or known as Coronavirus Disease (COVID-19) entered Indonesia, all policies in all sectors are directed to be online, including the education and learning sector. ${ }^{1}$ This policy applies from elementary school to the university level. The schools and universities that have good facilities, infrastructures, and human resources may easily adjust the switching learning from offline to online. However, those who do not have adequate facilities,

1 Noor Amalina Audina and Mahfuz Rizqi Mubarak, "Strategi Metakognitif dalam Belajar Bahasa Arab di Era Pandemi Covid-19: Analisis Persepsi Mahasiswa", Proceeding NATHLA : al-Nadwah al-'Alamiyyah fi Ta'lim al-Lughah al-'Arabiyyah, Vol. 1, No. 1,2020, 161-166; Apri Wardana Ritonga et al., "Teacher's Challenges in Implementing HOTS in Learning Arabic During Covid-19 Pandemic", Izdibar: Journal of Arabic Language Teaching, Linguistics, and Literature, Vol. 4, No. 1, 2021, 2. 
infrastructure, and human resources will find the difficulties this changing mode of learning. In these situations, learners may experience fear, confusion, or even boredom with the platform they used to learn online. Therefore, this focus of learning is very important in both online and offline learning contexts, especially in language learning. ${ }^{2}$

The most supportive facility and infrastructure in conducting online learning is the presence of technology. One thing that is easy to reach and tends to be widely used by students is social media. Various social media are still widely used by Indonesians, both students, and non-student. Technology has affected various sectors and all small aspects of human life, including learning aspects, especially Arabic learning. Before the Covid-19 virus began to appear in Indonesia, the use of technology in learning had been widely used and developed. Technology coupled with an internet connection is the main tool in supporting the learning process, ${ }^{3}$ also called CALL (computers as assisted tools in language learning). ${ }^{4}$ The availability of the internet provides an opportunity for education providers to explore its application in their institutions. Where language teaching is concerned, many studies have found that it has a positive impact on learning. ${ }^{5}$

Technology-based social media such as Facebook, Twitter, Instagram, and others are starting to be widely used as tools of learning or media, in addition to several platforms that provide online learning models or called LMS (Learning Management System) such as Moodle (E-Learning), Quizzes, or Kahoot in learning quiz models. This not only changes learning behavior naturally (Manual) but also requires the mental development of human resources in utilizing technology and internet connections. ${ }^{6}$ Social media has created new possibilities for digital native students to engage, interact and collaborate on learning tasks that drive the learning process and the overall learning experience. Based on social constructivism, Mondahl and Rezmarita argue that foreign language learning is an individual and collaborative process and cognitive process that underlies learning and especially foreign language learning facilitated by social media and especially for the new generation of students. Mondahl and Rezmarita examine how to best use social media in an educational setting and how learning can be fostered socially, collaboratively constructing, sharing and building knowledge. They conclude that the collaborative learning process embedded in social media-based learning platforms is supportive and conducive to successful problem solving that leads to foreign language learning in adults.

${ }^{2}$ Joy Egbert, "The New Normal?: A Pandemic of Task Engagement in Language Learning", Foreign Language Annals, Vol. 53, No. 2, 2020, 315.

3 Mohammed Farrah and Nuraihan Mat Daud, "Quality Benchmarking for Online Writing Course: A Malaysian Case Study”, World Applied Sciences Journal, Vol. 21, 2013, 117-124.

4 Jomana S. Zboun and Mohammed Farrah, "Students' Perspective of Online Langauge Learning During Corona Pandemic: Benefits and Challenges", Indonesian EFL Journal, Vol. 7, No. 1, 2021, 13-20.

${ }^{5}$ Farrah and Mat Daud, "Quality Benchmarking for Online Writing Course".

${ }^{6}$ Ken Beatty, Teaching and Researching Computer-Assisted Language Learning, 2nd ed., Applied linguistics in action, (Harlow, England; New York: Longman, 2010), 7. 
Furthermore, they saw some challenges in using social media for teaching and learning process at university level. $^{7}$

Language learning, especially in learning Arabic in the Covid-19 era, has also forced to change the learning model to be online-based. A lecturer certainly requires creativity in developing online-based learning. This is needed to make learning less boring and to change learning behavior from manual to virtual classes. With consideration to suppress the transmission of Covid-19 in the educational environment. The challenges are not so easy; even though the development of technology has been growing, the competence of each lecturer varies in the use of technology in learning. In addition to this, it is also to produce new learning models that are not only manual classes but also virtual classes that allow the learning process to occur in different conditions,especially in dealing with learning in the postpandemic era. Unfortunately, the profiles and motivations of students in this generation of COVID-19 tend to be very different. This difference is due to the fact that they have fewer options, and these need to be considered when developing online teaching. ${ }^{8}$

Research conducted by Ortagus ${ }^{9}$ explains that there is a statistical change in the background of undergraduate students in higher education in America from 2000 to 2021. He reveals that most who enroll in bold learning programs come from students who work full-time or are married and parents. Also said Tallents, ${ }^{10}$ et al that since 2006, students who enroll in classes based on certain things and focus on learning outcomes. This means that adjustments to situations and conditions may occur. However, the presence of technology and the internet in the 4.0 era towards the 5.0 era needs to be a challenge as a learning model development.

According to Munir and Muassomah, ${ }^{11}$ the research on learning Arabic in the Pandemic era implemented e-learning in the learning process at the elementary school level. This study concludes that the use of technology (e-learning) in learning Arabic has advantages and disadvantages. Its advantages include providing opportunities for students and lecturers to be more creative and innovative, providing flexible time, and providing easy access to learning resources. While the shortcomings that can be observed are that not all students have an Android cellphone or laptop to support the implementation of e-learning-based Arabic learning. Uneven internet access, lack of

${ }^{7}$ Margrethe Mondahl and Liana Razmerite, "Social Media, Collaboration and Social Learning - a Case-Study of Foreign Language Learning”, The Electronic Journal of E-Learning, Vol. 12, No. 4, 2014, 339-352.

${ }^{8}$ Zalfa Feghali et al., "Teaching Online in the Age of COVID-19", Journal of American Studies, Vol. 55, No. 1, 2021, 213.

9 Justin Ortagus, "From the Periphery to Prominence: An Examination of the Changing Profile of Online Students in American Higher Education", The Internet and Higher Education, Vol. 32, 2016, 52.

${ }^{10}$ Mary K. Tallent-Runnels et al., "Teaching Courses Online: A Review of the Research", Review of Educational Research, Vol. 76, No. 1, 2006, 112.

11 Achmad Sirojul Munir and Muassomah, "Pembelajaran Bahasa Arab Di Era Pandemi: Implementasi E-Learning Di Sekolah Dasar Islamic Global School Kota Malang”, Lisanul Arab: Journal of Arabic Learning and Teaching, Vol. 10, No. 1, 2021, 101. 
supervision, and reduced interaction between lecturers and students in the process of teaching and learning activities are also the barriers online learning might face.

According to Deviana and Mubaarokah ${ }^{12}$, brainstorming patterns and metaphors were carried out in the online teaching and learning process. This is due to government policies to reduce the spread of Covid-19. Lecturers try to create a fun learning atmosphere to achieve learning goals, by publishing the results of the text, Insyâ burr on Instagram. This learning includes four aspects of creativity, namely flexibility, originality, and elaboration, by bringing up new and different ideas for each student without any influence and impression of blaming the lecturer for the student's creativity process, the lecturer as a reviewer and motivator.

The presence of the era of technology encourages educational institutions and practitioners to change the role model of learning by looking at the capabilities and limitations of infrastructure. The era of social media, which is considered closer to the daily lives of students, is considered to have a good effect on improving learning and learning achievement. Social media cannot be used in every aspect of learning, but its presence can be assessed as optional in choosing learning media.

Based on the background above, the authors conducted research on student perspectives of learning Arabic using social media, particularly, Instagram. How students see learning models in the social media-based pandemic era can be elaborated with learning in the post-covid-19 pandemic era. Perspectives of connections are different in each area because learning takes place in each area with a different internet connection. Then the perspective of the availability of internet-based media that is easy to use and also cheap. This article explored students' perspectives of Arabic learning with Instagram in the post-pandemic era.

\section{Method}

This research used a qualitative descriptive method to explain findings or field data in the description of the analysis. The author explained students' perspectives of learning Arabic using Instagram. This research was carried out during the even semester of the 2020/2021 academic year to gain better insight into students' perspectives on online learning and the possibilities for enhancing it at Imu Hadis department, Faculty of Ushuluddin and Adab, Sultan Maulana Hasanuddin State Islamic University Banten. The questionnaire that was created was integrated with the EDOM system (Evaluation of Lecturers by Students) to see the overall perspective of students in online-based Arabic learning with one of the elements being the use of Instagram.

12 Ade Destri Deviana and Lailatul Mubaarokah, "Brainstorming and Methapor Patterns in Creativity, Insya Hurr, Through Online Learning on Instagram Hashtags", Izdihar: Journal of Arabic Language Teaching, Linguistics, and Literature, Vol. 4, No. 1, 2021, 38. 


\section{Arabiyât Jurnal Pendidikan Bahasa Arab dan Kebahasaaraban, 8 (2), 2021}

\section{Result and Discussion}

Stages of Online Learning Before and During the Covid-19 Pandemic

According to Roberts and Pennington ${ }^{13}$, Singh, Farrah ${ }^{14}$, Daud \& Farrah, ${ }^{15}$ online learning has undergone various stages of development. The first stage of implementing bold learning begins with using a system called CALL (computer as assisted tools in language learning). CALL started in several universities in 1980. At that time, CALL was only a set of enhancements to complement teaching such as CDROMs and online conferences. The rapid development of CALL has made CALL a system that is widely used by instructors and institutions that are combined with inclass and out-of-class learning systems. It aims to have traditional learning with a certain bold learning model to promote the learning process. Another reference explains that CALL is divided into 3 stages. It has started precisely since 1960. The first stage is called Behavioristic CALL, Communicative CALL and Integrative CALL. This stage refers to the level of technology such as the pedagogical approach. ${ }^{16}$

In the era of the pandemic, the government began to make and enforce policies in almost all sectors including education to do work from home. The term "Work from Home" (WfH) began to appear. This includes the education sector. Teaching and learning activities are carried out at almost all levels of education, from elementary school to university. Learning that is carried out virtually undergoes several stages in the pandemic era. Starting from setting up a temporary device to a continuous device. However, several weaknesses such as the availability of technology media and internet connections become obstacles in the overall online learning stage. ${ }^{17}$ Not to mention the use of social media as a medium for conducting teaching and learning activities, such as making learning videos on the YouTube Channel, Live Streaming on Facebook and Instagram up to using social media as a medium to evaluate learning (Kahoot, Quizzes, etc) ${ }^{18}$ and portfolio assignments.

Singh and Thurman ${ }^{19}$ explain that students experience two sides of online learning. Synchronous and asynchronous learning and utilizing various technology-

13 Ralph J. Roberts and Bruce F. Pennington, "An Interactive Framework for Examining Prefrontal Cognitive Processes”, Developmental Neuropsychology, Vol. 12, No. 1, 1996, 105-126.

${ }^{14}$ Farrah. M., "An Evaluation of an Online English for Academic Writing Program Using the IHEP 2000 Quality Agreed upon Benchmarks”, Thesis, IIUM, Malaysia, 2006.

${ }^{15}$ Farrah and Mat Daud, "Quality Benchmarking for Online Writing Course".

16 Mark Warschauer and Deborah Healey, "Computers and Language Learning: An Overview", Language Teaching, Vol. 31, No. 2, 1998, 57-71.

17 Yuda Pratama and Nabila Qurrota A'yun, "Kelompok Belajar Mahasiswa Di Masa Pandemi Covid-19: Solusi Alternatif Pemodelan Pembelajaran Bahasa Arab Di Era Pandemic", Multaqa Nasional Bahasa Arab, Vol. 3, No. 1, 2020.

18 According to Fiani et al. concluded that the use of Kahoot! application in Arabic vocabulary learning for the fifth-grade students at MI Al-Ma'arif 01 Margomulyo can improve the students' learning outcomes. Irma Nur Fiani, Mohammad Ahsanuddin, and Romyi Morhi, "The Effectiveness of Using Kahoot! Application as An Evaluation Tool in Arabic Vocabulary Learning at Madrasah Ibtidaiyah", Izdihar: Journal of Arabic Language Teaching, Linguistics, and Literature, Vol. 4, No. 2, 2021, 252.

${ }^{19}$ Vandana Singh and Alexander Thurman, "How Many Ways Can We Define Online Learning? A Systematic Literature Review of Definitions of Online Learning (1988-2018)", American Journal of Distance Education, Vol. 33, No. 4, 2019, 289-306. 


\section{Arabiyât Jurnal Pendidikan Bahasa Arab dan Kebahasaaraban, 8 (2), 2021}

based learning media connected to the internet. In this condition, students can communicate anywhere and anytime. Communicating with friends and lecturers to support good learning. Unlimited access to data and information for devices connected to the internet. In times where pandemics became a part of life and after the Covid-19 situation, most institutions still implemented synchronous online classes.

The use of network-based multimedia, according to research conducted by Vandergrift $^{20}$, opens the door to a large source of reference for practicing language skills, such as listening, reading and others. He also said that wider access to networkbased technology would likely shift the focus of learning from the classroom to independent learning. This means that the use of network-based technologies such as the presence of social media can change the way a person views learning. This includes learning Arabic. Classes may be considered as a place to get knowledge references. In this case, social media can be a tool to gain knowledge, including Arabic language skills.

The stages of the development of online learning do not only extend to the provision of online media in order to overcome the force major, but also can produce hybrid learning concepts while still exercising control over the learning process and outcomes. Every educational institution as well as the government is pushing for improvement and development of learning models by adjusting to current needs and conditions. Covid-19 not only forces the education sector to carry out learning but also gives warnings to prepare for learning from the 4.0 to 5.0 era. According to Carey the most basic and crucial thing with the Covid-19 pandemic is to respond to it by providing quality online education and a transmission mechanism from traditional learning to online learning. ${ }^{21}$ In his statement in The New York Times, Carey ${ }^{22}$ said that:

"One consequence of the coronavirus: It will become clearer that good online education is easier said than done."

In the pandemic and post-pandemic era, the use of technology such as social media, of course, changes the existence of teachers as centers of knowledge into facilitators. As a facilitator, a teacher must know more in many ways than just a giver of information. Facilitators should be aware of the variety of materials available to improve students' language skills, not just one or two texts. They also need to know how to teach students to use the material effectively. The teacher as a facilitator must be able to respond to the needs of the students and adapt to something close to students such as social media and not just based on the determination of curriculum development ideas. With this in mind, teachers can improve and develop learning

20 Larry Vandergrift, "Recent Developments in Second and Foreign Language Listening Comprehension Research", Language Teaching, Vol. 40, No. 3, 2007, 191-210.

21 As cited in Shivangi Dhawan, "Online Learning: A Panacea in the Time of COVID-19 Crisis”, Journal of Educational Technology Systems, Vol. 49, No. 1, 2020, 5-22.

${ }^{22}$ Kevin Carey, "Everybody Ready for the Big Migration to Online College? Actually, No", The New York Times, March 13, 2020, sec. The Upshot, accessed October 14, 2021, https://www.nytimes.com/2020/03/13/upshot/coronavirus-online-college-classes-unprepared.html. 
models, media and learning tools based on situations and conditions to help improve students' learning of foreign languages, especially Arabic. ${ }^{23}$

\section{Learning Transformation from Manual to Online Class}

Carey's statement emphasized that the crucial issue of the Covid-19 pandemic was the improvement of the education system in supporting good learning. The online learning policy is not only based on the Covid-19 pandemic but also on the creation of a learning atmosphere based on the context and conditions. Learning is not limited by space and time. Learning activities are based on students' needs for science and as a medium for transforming and sharing knowledge from teachers to students.

One of the challenges of a teacher is to produce HOTS (Higher Order Thinking Skills) learning in Arabic learning during the Covid-19 Pandemic era. According to Ritonga et al, the Covid-19 pandemic is an obstacle for teachers in carrying out HOTS-based Arabic learning because the 30-minute time allocation is considered insufficient to improve students' HOTS abilities. These challenges come from three main sectors, namely from students, from teachers, and from school infrastructure that does not support the implementation of HOTS. The solution is for learning teachers to deepen their understanding of the HOTS concept and the steps for its application in learning Arabic. Thus, with the conditions of online learning in the midst of the Covid-19 pandemic, HOTS-based Arabic learning remains consistently implemented. ${ }^{24}$

Transforming classes from manual classes to online classes certainly has its challenges and advantages. The readiness of lecturers and students is also a consideration. It is also the main thing about the internet connection in each of the various individuals is also a challenge. According to Zboun and Farrah that Covid-19 has forced academic institutions around the world to change the traditional way of learning to online-based learning. Therefore, the discussion of synchronous online class-based learning becomes a crucial topic. ${ }^{25}$ This discussion is certainly more interesting if students are involved in giving opinions about the implementation of online learning. In this regard, Reinhardt ${ }^{26}$ explained that:

"As long as meaningful social interaction has been understood as necessary for language learning, language educators have sought to integrate a means for communicative practice into teaching. Some of the first Internet applications for synchronous (chat) and asynchronous (email and bulletin board system) communicative exchange were identified as having educational potential, and teachers began implementing them, and researchers investigating them, as soon as it was logistically feasible."

${ }^{23}$ Warschauer and Healey, "Computers and Language Learning: An Overview".

24 Ritonga et al., "Teacher's Challenges in Implementing HOTS in Learning Arabic During Covid-19 Pandemic", 10.

25 Zboun and Farrah, "Students' Perspectives of Online Language Learning During Corona Pandemic", 19.

${ }^{26}$ Jonathon Reinhardt, "Social Media in Second and Foreign Language Teaching and Learning: Blogs, Wikis, and Social Networking”, Language Teaching, Vol. 52, No. 1, 2019, 1-39. 


\section{Arabiyât Jurnal Pendidikan Bahasa Arab dan Kebahasaaraban, 8 (2), 2021}

The researcher conducted a survey to see student responses about the transformation of manual classes into online classes using a Likert scale to 31 students in Arabic class. The researcher explains in the diagram below:

I prefer traditional (Manual) classes

Figure 1. Diagram of Prefer to Traditional Class and Online Class

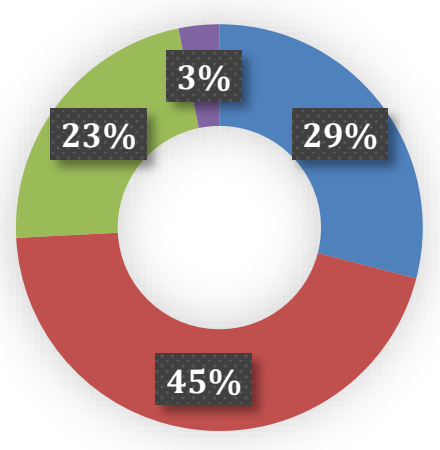

- I Prefer Online Class

- I Prefer Manual Class

- I Prefer Online and Manual Class

No Answer

According to the diagram above, it shows that $45 \%$ prefer learning to be carried out using a manual system or traditional classroom (face-to-face classes). 29\% prefer online classes (virtual classroom), 23\% prefer online classes and traditional classes went hand in hand according to their needs and 3\% did not make a choice.

I participate more in manual classes

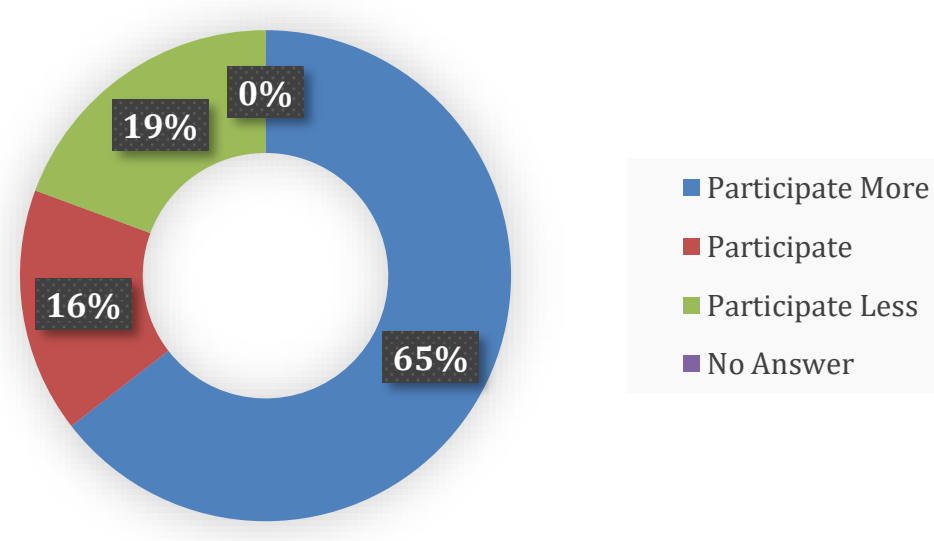

Figure 2. Diagram of Participation in Manual Class than Online Class

According to the diagram above, it shows that 65\% participated more in manual classes than online classes. $16 \%$ participated in manual class, $19 \%$ participated less in manual class than online class and $0 \%$ did not make a choice, than from this diagram above students participate more in manual classes.

Interaction with lecturer in online classes is less than interaction in manual classes

Students' participation more in manual class than online class was influenced the interaction between students and lecturer in an online class than in manual class. It's illustrated in the diagram below. 


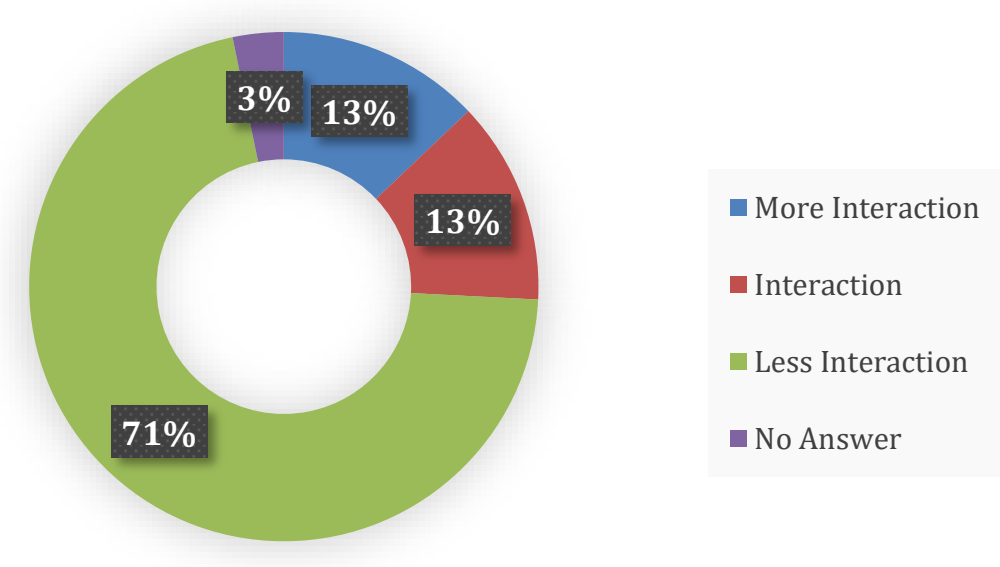

Figure 3. Diagram of Interaction between Students and Lecturer

The diagram above shows that $71 \%$ less interaction with lecturers in online classes than in manual classes. $13 \%$ interacted with lecturer in a manual and online class, $13 \%$ more interaction with lecturer in manual class than online class and 3\% did not make a choice.

\section{Instructors and students need training courses to make online courses more beneficial}

The last response regarding the transformation of manual classes into online classes was a discussion about providing online learning models for students and lecturers. Students voice that not all lecturers and students know how to use social media and create the lecturing with social media in online classes. Therefore, students and lecturers need training courses to make the online classes more beneficial and make a good online class. According to Muradi et $\mathrm{al}^{27}$, they talk about freedom to learn perspective in online Arabic learning that online learning is to create an innovation and make a new culture of learning between lecturer and students. They said that innovation is an important part for lecturers to affect the students' independence in learning.

According to Jessner ${ }^{28}$ the challenging ways that have been suggested to achieve multilingualism for all should be addressed to students, teachers, educators and policy makers. It is argued that multilingual education can only be successful if language teaching is generally restructured and oriented towards multilingual norms. Jessner in his research said that in teaching a third language, the implementation of the concepts related to it is very necessary. So that it is not only an important part of language education that is considered important but also language teaching in general. He said that there are two main concepts that need to be considered. First, the

${ }^{27}$ Ahmad Muradi et al., "Tutors and Students Activities in Online Arabic Learning: A Freedom to Learn Perspective," Arabiyat: Jurnal Pendidikan Bahasa Arab dan Kebahasaaraban 8, no. 1 (June 30, 2021): 32-45, 43.

28 Ulrike Jessner, "Teaching Third Languages: Findings, Trends and Challenges," Language Teaching 41, no. 1 (2007): 15-56, https://doi.org/10.1017/S0261444807004739. 
language taught in the classroom needs to be linked to benefit from synergies and to exploit the resources that many students already have through their prior knowledge of the language. Second, a portfolio or some other form of documentation of linguistic background should be required in every class so that the advantages or positive effects of multilingualism can be identified and ultimately utilized. In this way awareness of students' multilingualism can be provided for both teachers and fellow students.

\section{Arabic learning process with Instagram}

Students make a self-introduction video in Arabic. Students explore selfintroduction videos in Arabic by adding Arabic subtitles and translations during the video. When the video is uploaded to Instagram, students add a description in the Description column on Instagram using Arabic. In the description column, students add hashtags as keywords to make it easier for lecturers to find videos as a whole from individual students.

The process of learning Arabic using Instagram is intended to train students in speaking Arabic and writing descriptions or captions in Arabic. Another positive thing that can be taken from learning activities like this is the feedback from fellow students and Instagram followers to correct each other. In this activity, the lecturer only becomes a facilitator who encourages students to be able to optimize learning activities through Instagram social media. Ratings will usually come from connoisseurs of social media content. Lecturers will see the extent to which learning models like this can have an impact on improving students' language skills.

Figure 4 below describes the Arabic learning process on Instagram. The student introduces himself in Arabic on video and he describes the text in Arabic on the description column. The other student can give feedback or correction on the comment column. The interaction with other students and lecturers can be found with this social media (Instagram).

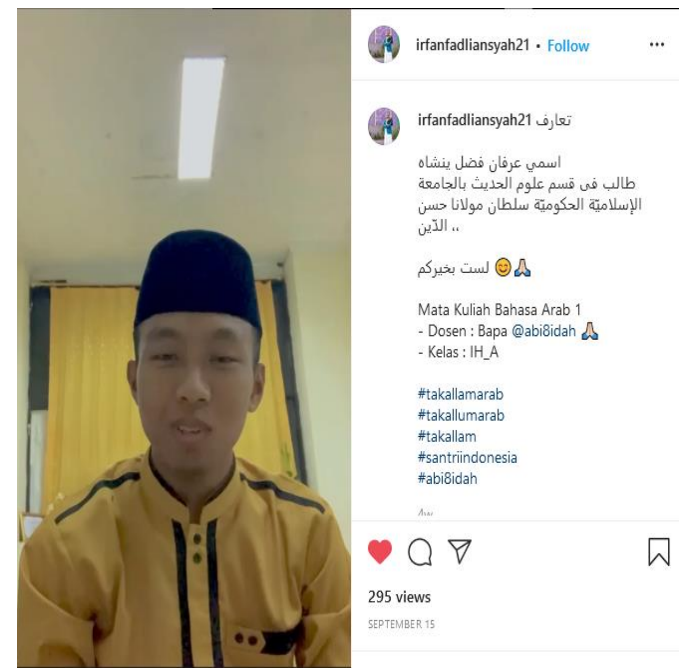

Figure 4. Students compile a self-introduction with video and description (caption) 
In the process, the lecturer asked all students to create a self-introduction video in Arabic. The video must include part of the introduction, like full name and family name, home address, department, and why student should learn Arabic? Students write the description in column in Arabic.

I prefer Arabic learning with Instagram

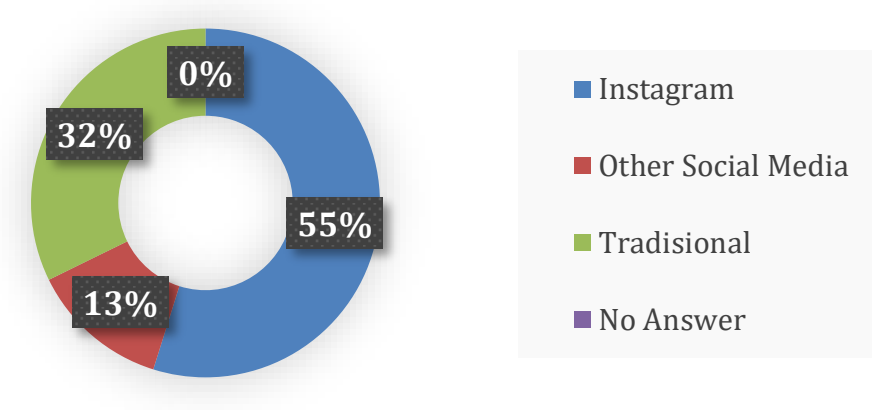

Figure 5. Diagram of Instagram Prefered

Figure 5 describes that most of the students preferred Arabic learning with Instagram. 55\% prefer Arabic learning with Instagram. 13\% prefer with other social media. 32\% prefer Arabic learning in a traditional class.

\section{I spend more time and effort in Arabic learning with Instagram}

Students assess the differences when studying in traditional classes (face to face) with learning using Instagram. They said that learning using Instagram is not bound by time as in traditional classroom learning. But they need more time to prepare the material in Arabic learning. They must prepare a good and correct text according to the rules as well as intonation and pronunciation when taking videos about self-introductions in Arabic. Although basically, online learning does not take much time because of some conditions that allow it to only take a little time, such as a weak connection, inadequate internet quota and etc.

Arabic learning with Instagram needed more time and spend it for preparing the materials, students' voices.
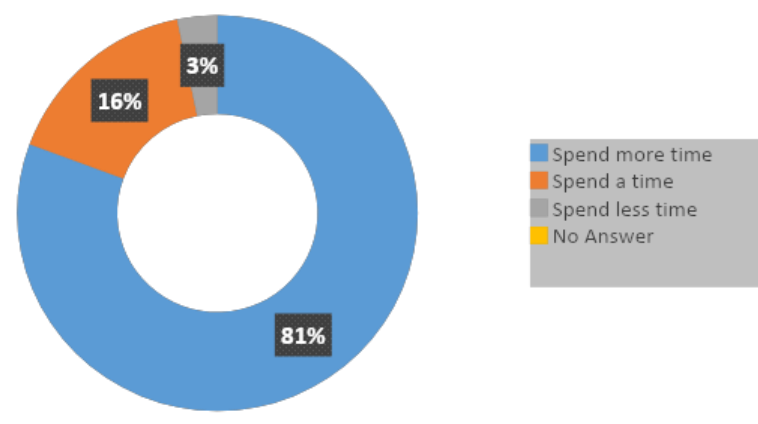

Figure 6. Spend More Time and Effort in Arabic Learning with Instagram 
Figure 6 showed that $81 \%$ of students spend more time in Arabic learning with Instagram. $16 \%$ of students spend a little time in Arabic learning with Instagram. $3 \%$ students spend less time and $0 \%$ of student did not answer.

\section{I prefer submitting my assignment via Instagram}

More students prefer submitting their assignments via Instagram. Instagram will display videos uploaded on their respective Instagram accounts. Of course, the uploaded video will get feedback, especially from Instagram followers. Because of this, they argue that learning Arabic using Instagram makes them more prepared in finishing the assignment and the material to be uploaded to Instagram.

\section{I feel relaxed in Arabic learning with Instagram}

Students feel relaxed when learning with Instagram either during live streaming or task-based learning by uploading assignments via Instagram. This is due to the preparation they have done before the learning takes place.

\section{Arabic learning with Instagram is easy to reach}

Referring to responses about feeling relaxed while studying with Instagram. Students also considered that learning Arabic with Instagram is very easy to reach with technological developments and they were getting closer to gadgets. The problem was in weak connection or lost connection. More students' perceptions show an interest in learning Arabic with Instagram because some materials can be developed through Instagram media such as speaking and writing skills in Arabic.

\section{Conclusion}

The conclusion in this study is that online-based Arabic learning using Instagram social media has a good perception based on student voices. Online-based Arabic learning using Instagram is considered to be able to present a relaxed atmosphere in learning Arabic while playing social media. Students consider Instagram as a medium to promote Arabic on social media through learning to speak and write. This study aimed that Arabic learning with Instagram students' voice as a solution of the many social media used for learning. Students relax, participate more, and prefer to use Instagram in Arabic learning through speaking skill and writing.

Social media-based learning is considered very innovative and creative. Students can use social media such as Instagram to present the results of assignments from learning Arabic. The process of monitoring and evaluating learning outcomes can be carried out by teachers and even fellow students and or outside students. Students who are members of learning classes can provide evaluations or feedback according to their knowledge of a theme. Students can also get feedback from people outside the classroom. Therefore, Instagram is considered as a tool that can be used for learning Arabic, especially in writing and speaking skills. Instagram is considered as a creative and innovative media as the use of social media in learning Arabic. [ 


\section{REFERENCES}

Audina, Noor Amalina., and Mahfuz Rizqi Mubarak. "Strategi Metakognitif dalam

Belajar Bahasa Arab di Era Pandemi Covid-19: Analisis Persepsi Mahasiswa", Proceeding NATHLA: al-Nadwah al-'Alamiyyah fi Ta'lim al-Lughah al-'Arabiyyah, Vol. 1, No. 1, 2020.

Beatty, Ken. Teaching and Researching Computer-Assisted Language Learning. 2nd ed. Applied linguistics in action. Harlow, England; New York: Longman, 2010.

Carey, Kevin. "Everybody Ready for the Big Migration to Online College? Actually, No", The New York Times, March 13, 2020, sec. The Upshot. Accessed October 14, 2021. https://www.nytimes.com/2020/03/13/upshot/coronavirus-onlinecollege-classes-unprepared.html.

Deviana, Ade Destri., and Lailatul Mubaarokah. "Brainstorming and Methapor Patterns in Creativity, Insya Hurr, Through Online Learning on Instagram Hashtags", Izdibar: Journal of Arabic Language Teaching, Linguistics, and Literature, Vol. 4, No. 1, 2021.

Dhawan, Shivangi. "Online Learning: A Panacea in the Time of COVID-19 Crisis", Journal of Educational Technology Systems, Vol. 49, No. 1, 2020.

Egbert, Joy. "The New Normal?: A Pandemic of Task Engagement in Language Learning", Foreign Language Annals, Vol. 53, No. 2, 2020.

Farrah, Mohammed., and Nuraihan Mat Daud. "Quality Benchmarking for Online Writing Course: A Malaysian Case Study”, World Applied Sciences Journal, Vol. 21, 2013.

Farrah, M. "An Evaluation of an Online English for Academic Writing Program Using the IHEP 2000 Quality Agreed upon Benchmarks", Thesis, International Islamic University Malaysia, 2006.

Feghali, Zalfa., Ben Offiler, Miguel Hernández, Cassandra L. Clark, Kaisha Esty, Emma Battell Lowman, Gavan Lennon, and Rebecca Barrett-Fox. "Teaching Online in the Age of COVID-19", Journal of American Studies, Vol. 55, No. 1, 2021.

Fiani, Irma Nur., Mohammad Ahsanuddin, and Romyi Morhi. "The Effectiveness of Using Kahoot! Application as An Evaluation Tool in Arabic Vocabulary Learning at Madrasah Ibtidaiyah", Izdihar: Journal of Arabic Language Teaching, Linguistics, and Literature, Vol. 4, No. 2, 2021.

Jessner, Ulrike. "Teaching Third Languages: Findings, Trends and Challenges", Language Teaching, Vol. 41, No. 1, 2007.

Mondahl, Margrethe., and Liana Razmerite. "Social Media, Collaboration and Social Learning - a Case-Study of Foreign Language Learning", The Electronic Journal of E-Learning, Vol. 12, No. 4, 2014.

Munir, Achmad Sirojul, and Muassomah Muassomah. "Pembelajaran Bahasa Arab Di Era Pandemi: Implementasi E-Learning Di Sekolah Dasar Islamic Global 
School Kota Malang”, Lisanul Arab: Journal of Arabic Learning and Teaching, Vol. 10, No. 1, 2021.

Muradi, Ahmad., Jamal Syarif, Fatwiah Noor, and Arif Rahman Hakim. "Tutors and Students Activities in Online Arabic Learning: A Freedom to Learn Perspective", Arabiyat: Jurnal Pendidikan Bahasa Arab dan Kebahasaaraban, Vol. 8, No. 1, 2021.

Ortagus, Justin. "From the Periphery to Prominence: An Examination of the Changing Profile of Online Students in American Higher Education", The Internet and Higher Education, Vol. 32, 2016.

Pratama, Yuda., and Nabila Qurrota A'yun. "Kelompok Belajar Mahasiswa Di Masa Pandemi Covid-19: Solusi Alternatif Pemodelan Pembelajaran Bahasa Arab Di Era Pandemic", Multaqa Nasional Bahasa Arab, Vol. 3, No. 1, 2020.

Reinhardt, Jonathon. "Social Media in Second and Foreign Language Teaching and Learning: Blogs, Wikis, and Social Networking”, Language Teaching, Vol. 52, No. 1, 2019.

Ritonga, Apri Wardana., Wildana Wargadinata, Nur Hasan, and Bakri Mohammad Bkheet Ahmad. “Teacher's Challenges in Implementing HOTS in Learning Arabic During Covid-19 Pandemic", Izdihar: Journal of Arabic Language Teaching, Linguistics, and Literature, Vol. 4, No. 1, 2021.

Roberts, Ralph J., and Bruce F. Pennington. "An Interactive Framework for Examining Prefrontal Cognitive Processes", Developmental Neuropsychology, Vol. 12, No. 1, 1996.

Singh, Vandana., and Alexander Thurman. "How Many Ways Can We Define Online Learning? A Systematic Literature Review of Definitions of Online Learning (1988-2018)", American Journal of Distance Education, Vol. 33, No. 4, 2019.

Tallent-Runnels, Mary K., Julie A. Thomas, William Y. Lan, Sandi Cooper, Terence C. Ahern, Shana M. Shaw, and Xiaoming Liu. "Teaching Courses Online: A Review of the Research", Review of Educational Research, Vol. 76, No. 1, 2006.

Vandergrift, Larry. "Recent Developments in Second and Foreign Language Listening Comprehension Research”, Language Teaching, Vol. 40, No. 3, 2007.

Warschauer, Mark., and Deborah Healey. "Computers and Language Learning: An Overview", Language Teaching, Vol. 31, No. 2, 1998.

Zboun, Jomana S., and Mohammed Farrah. "Students' Perspective of Online Langauge Learning During Corona Pandemic: Benefits and Challenges", Indonesian EFL Journal, Vol. 7, No. 1, 2021. 